\title{
The Rosebel gold mining district (Trans-Amazonian belt, Suriname), a new structural framework
}

\author{
Denis Gapais ${ }^{1, *}$, Gilian Alimoenadi ${ }^{2}$, Nicole Balraadjsing ${ }^{2}$ and Benoît Poupeau ${ }^{2,3}$ \\ ${ }^{1}$ Géosciences Rennes, UMR CNRS 6118, Université de Rennes 1, 35042 Rennes cedex, France \\ 2 IAMGOLD, Heerenstraat 8, P.O. Box 2973, Paramaribo, Suriname \\ ${ }^{3}$ Kinross Gold Corporation, Tasiast Mauritania Ltd SA, ZRA 741, P.O. Box 5051, Nouakchott, Mauritania
}

Received: 14 September 2020 / Accepted: 18 May 2021 / Publishing online: 11 June 2021

\begin{abstract}
The Rosebel gold district belongs to the Paleoproterozoic Trans-Amazonian belt associated with sub-meridian crustal shortening. Here, we present new structural observations (cleavage, stretching lineations, veins, fault slip data, aeromagnetic map). The regional cleavage is steeply dipping and bears a steeply plunging stretching lineation. Finite strains are of flattening type. Fault slip data reveal a complex deformation history. The overall strain pattern in the area reflects vertical motions, a feature consistent with pop-down tectonics involving vertical stretch and burial of supracrustal deposits during horizontal shortening of a hot and weak continental lithosphere.
\end{abstract}

Keywords: Paleoproterozoic tectonics / Trans-Amazonian belt / Suriname / Rosebel gold district

Résumé - Le district aurifère de Rosebel (ceinture trans-amazonienne, Suriname), un nouveau modèle structural. Le district aurifère de Rosebel appartient à la ceinture tectonique paléoprotérozoïque de Trans-Amazonie régionalement associée à un raccourcissement crustal sub-méridien. Dans cet article, nous présentons de nouvelles données structurales et géophysiques sur le district (foliations, linéations, déformation finie, analyses des failles, carte aéromagnétique). La schistosité régionale a un fort pendage et porte une linéation d'étirement fortement plongeante. La déformation finie est de type aplatissement. Le champ de failles révèle une histoire de déformation progressive complexe, mais l'ensemble des données souligne une tectonique transpressive avec un raccourcissement sub-méridien et un étirement vertical de la croûte. Le champ de déformation reflète un enfouissement des dépôts supra-crustaux syn-tectoniques lors de la déformation compressive d'une lithosphère continentale chaude.

Mots clés : Tectonique paléoprotérozoïque / ceinture trans-amazonienne / Suriname / district aurifère de Rosebel

\section{Introduction}

The Rosebel gold district belongs to the Paleoproterozoic Trans-Amazonian belt (Fig. 1). The belt has a long-lasting tectonic history marked by successive deformation events that range from ca $2.3 \mathrm{Ga}$ to ca $1.9 \mathrm{Ga}$ (Delor et al., 2003; Daoust et al., 2011). At the regional map scale, gold occurrences are associated with supracrustal volcanics and sediments (Fig. 1) (Bardoux et al., 2018). A similar feature is also observed in western Africa (Gapais, 2018) that was linked to the TransAmazonian belt before the opening of the Atlantic Ocean. In a recent review paper, Gapais (2018) proposed that a common deformation mode of hot Paleoproterozoic belts was driven by vertical pop-downing of upper crustal deposits within

\footnotetext{
*Corresponding author: denis.gapais@univ-rennes1.fr
}

underlying weak ductile crustal layers, with associated implications for ore concentrations.

Here, we re-examine structural features that characterize the Rosebel area, especially pervasive structures (cleavage and stretching lineations), veins and fault arrays, aeromagnetic data. We further discuss implications for the deformation history of the belt and compare them with those expected in pop-downing tectonic models. Data presented were collected by the authors, the IAMGOLD mining company and collaborators in the Rosebel District. Although related to a limited area, these data are particularly important because the district is the only one currently exploited throughout the Trans-Amazonian belt rich in gold resources. This feature, the large amount of unpublished data collected in the Rosebel mining district, and the large-scale structural correlations with western Africa and its important mining potential, are the bases of the present paper. 


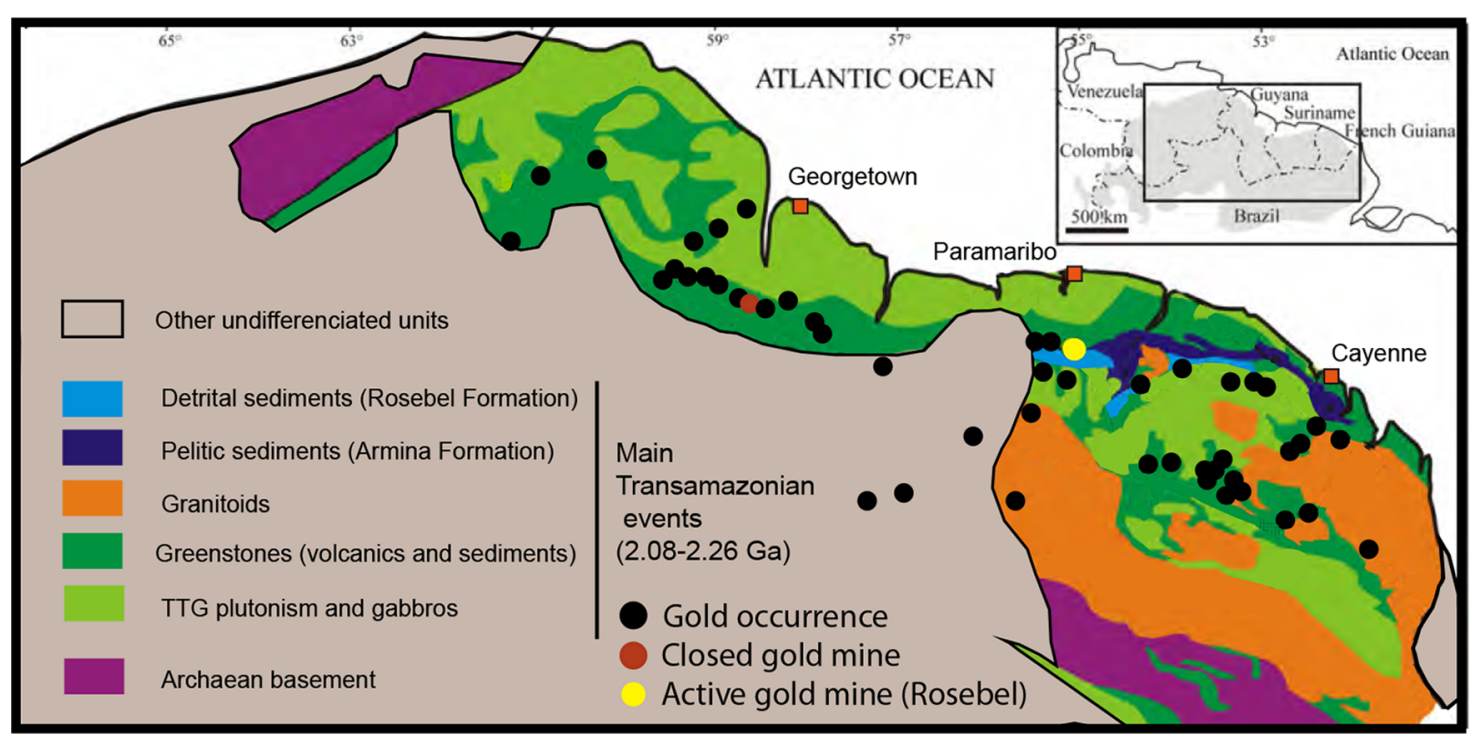

Fig. 1. Simplified geological map of the gold-bearing Trans-Amazonian Paleoproterozoic belt. The map underlines close relationships between supracrustal greenstones and sediments and gold occurrences. Modified after Delor et al. (2003) and Daoust et al. (2011).

\section{Geological setting}

The general geology and structure of the Rosebel area is shown in Figures 2 and 3. The district is localised within volcanics and detrital sedimentary series of Paleoproterozoic age that mainly consist of conglomerates, arenites, sandstones, and shales (Fig. 2a). Deposits are locally labelled as the Rosebel Group (equivalent to upper Detrital Unit in French Guiana). Deposition is attributed to basin development in a transtensional tectonic setting of regional scale (Delor et al., 2003; Vanderhaeghe et al., 1998). Metamorphic conditions that affect these series are of lower greenschist facies (Daoust et al., 2011; Daoust, 2016). The overall geometry of the area is a NW-SE trending synform with steep limbs bounded by steeply dipping faults (Fig. 2b). Aeromagnetic data underline the regional WNW-ESE structural trend (Fig. 3).

\section{Pervasive deformations}

A steeply dipping regional cleavage is well developed throughout the area (Fig. 2a) (Daoust et al., 2011; Daoust, 2016). Its overall EW to WNW-ESE strike is consistent with the overall trend illustrated by aeromagnetic data (Fig. 3). The cleavage is axial-plane of folds (Fig. 4a). Folds affect the regional bedding that trends EW to WNW-ESE. They are of various scales and are upright similar to isoclinal in shapes, with steeply dipping axial planes (Fig. 2) (Daoust et al., 2011; Daoust, 2016). Folds axes show variable plunges, a feature that might be consistent with variable amounts of fold reorientation according to local strains accumulated and timing of fold initiation during a progressive deformation associated with bulk vertical stretch. Consistently, the regional cleavage bears a well-developed stretching lineation with a down-dip plunge (Fig. 4b).

Pebble shapes in conglomerates have been measured throughout the district, in order to estimate finite strains.
Because preferred orientations of pebble long axes are rather strong (Fig. 4b), the Rf/ $\varphi$ method (Ramsay, 1967; Ramsay and Huber, 1983) was not used. Axial ratios of pebbles were measured on the principal strain planes, according to cleavage and stretching lineation attitudes. Results are shown on a Flinn diagram (Fig. 5) for four quarries where conglomerates are well represented. They emphasize that strains are of flattening type ( $K$ values between 0.55 and 0.75 ).

\section{Kinematic indicators}

Kinematic indicators attached to ductile structures are poorly expressed. They mainly consist of asymmetric shadow zones around clasts and asymmetrically deformed clasts in conglomerates within $\lambda 1 \lambda 3$ planes. These attest to vertical motions (Fig. 6a), a feature kinematically consistent with the observed scattering of syn-cleavage fold axes. A peculiar feature observed on many cleavage planes in the Rosebel quarries are very fine steeply plunging striations on cleavage surfaces (Fig. 6b). These suggest that the cleavage may have acted as an anisotropy-induced slip surface associated with vertical motions. This rather common and peculiar feature in the area would definitely require further study.

\section{Veins}

Veins are numerous in the area. Their range in width is mostly of the order of some $\mathrm{cm}$ to some $\mathrm{dm}$ and their length is limited (up to some tens of metres). They are generally made of quartz, \pm oxides, tourmaline, and pyrite, and constitute the main gold traps. A detailed description of the different types of veins is given in Daoust et al. (2011) and Daoust (2016). There are several vein sets with various attitudes, as follows:

- a set of veins present in all sites consists in tension gashes that show sub-horizontal or flat-lying attitudes (Fig. 7). 

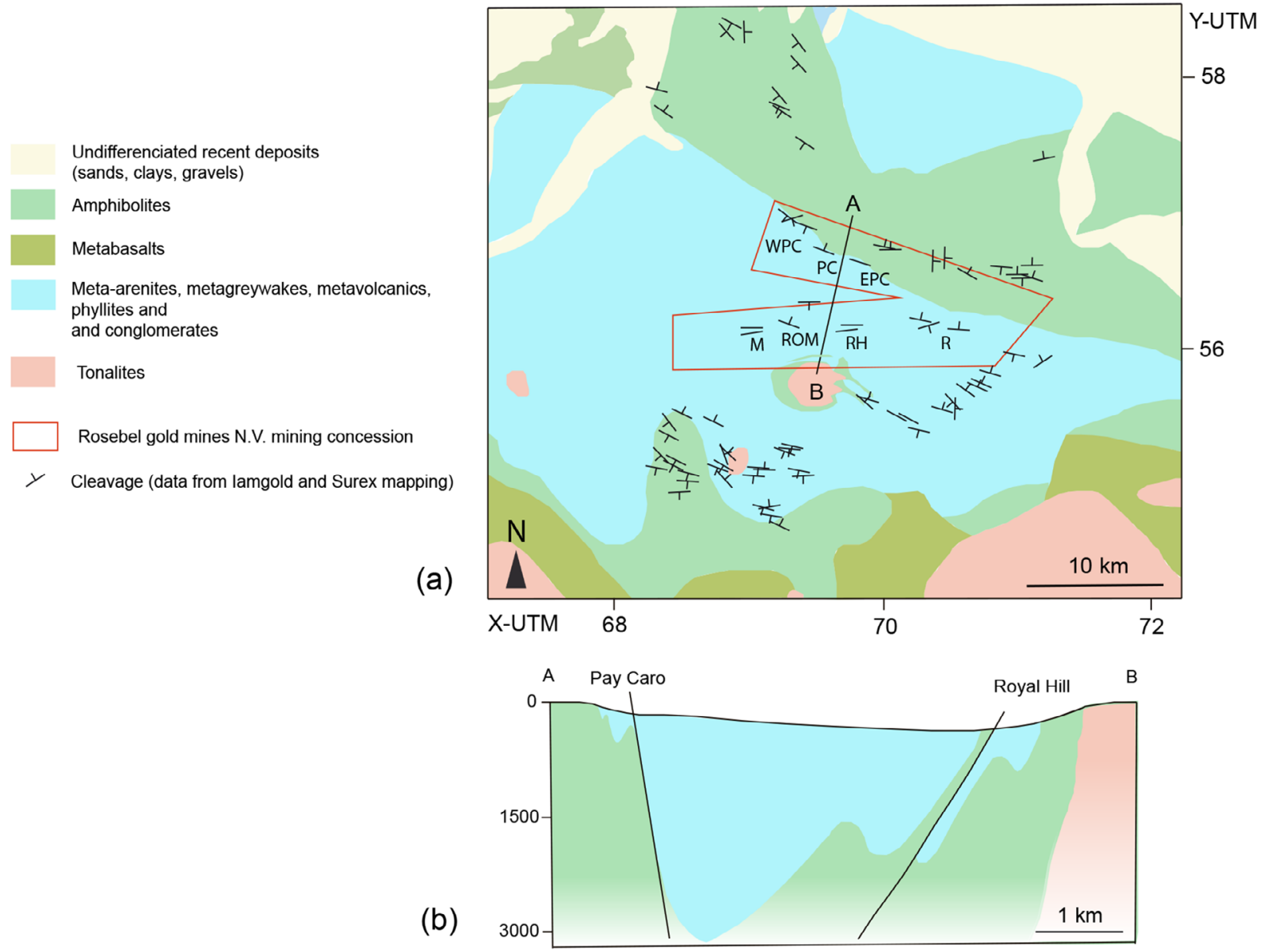

(a)

Fig. 2. (a) Simplified geological map of the Rosebel district. (b) Simplified cross-section localised on (a). The cross-section emphasizes the general synform geometry of the bedding, with associated steeply dipping cleavage as underlined by cleavage data shown in (a). WP: West Pay Caro pit; PC: Pay Caro pit; EPC: East Pay Caro pit; R: Rosebel pit; M: Mayo pit; ROM: Roma pit; RH: Royal Hill pit. Modified after Daoust et al. (2011).

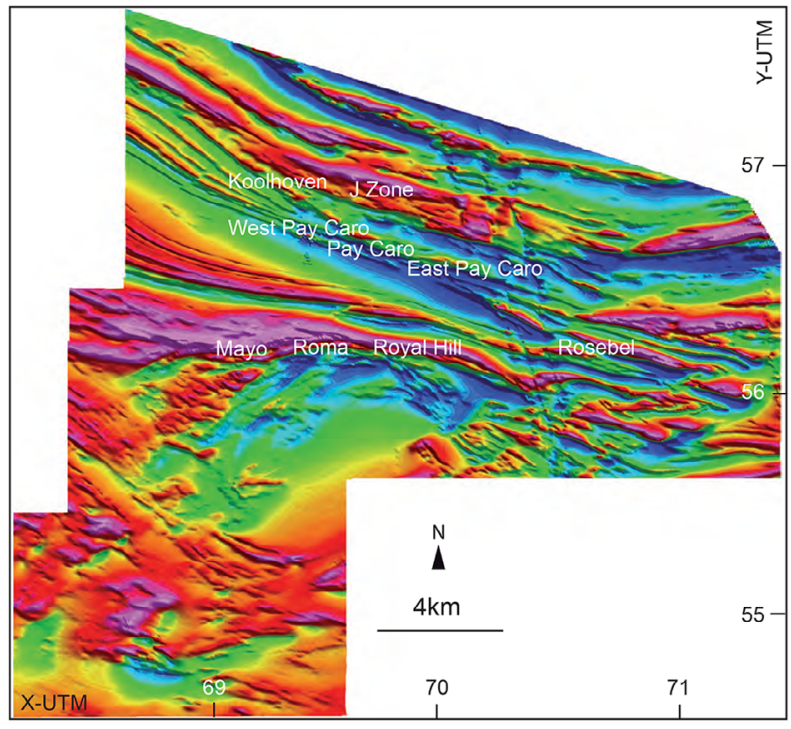

Fig. 3. Aeromagnetic map of the Rosebel district, with main pits indicated. The map underlines the overall trends of regional bedding and associated cleavage. The rounded structure in the southern part of the map (just South of Roma and Royal Hill pits) images the Brinks tonalitic body that crops out south of the mining concession (see Fig. 2).
These veins that bear main gold occurrences (Daoust et al., 2011) attest to vertical stretch. Other flat-lying veins localised in fold hinges have also been described and interpreted as buckling-induced openings (Daoust et al., 2011; Daoust, 2016);

- a set of subvertical NS striking veins is also present in all sites (Fig. 8). If one considers that the subvertical regional cleavage is perpendicular to the principal shortening and that the stretching lineation represents the principal stretch, this vein set reflects some bulk stretching along the intermediate strain axis, which is consistent with bulk flattening strains recorded by pebbles in conglomerates (Fig. 5). Comparable NS striking vein sets have been described in other parts of the Transamazonian belt (e.g. Milési et al., 1995; Milési et al., 2003);

- veins injected along the cleavage anisotropy or along major faults are also common (Fig. 9). Most trend EW to NNWSSE and were referred as "shear veins" by Daoust (2016).

Other sets of veins appear more local, often corresponding to "en-échelon" veins associated with individual faults.

Several vein sets are thus present; but no clear succession of vein sets could be made (Daoust et al., 2011). Furthermore, cross-cutting evidence does not show significant displacements along faults and unequivocal chronological relationships 

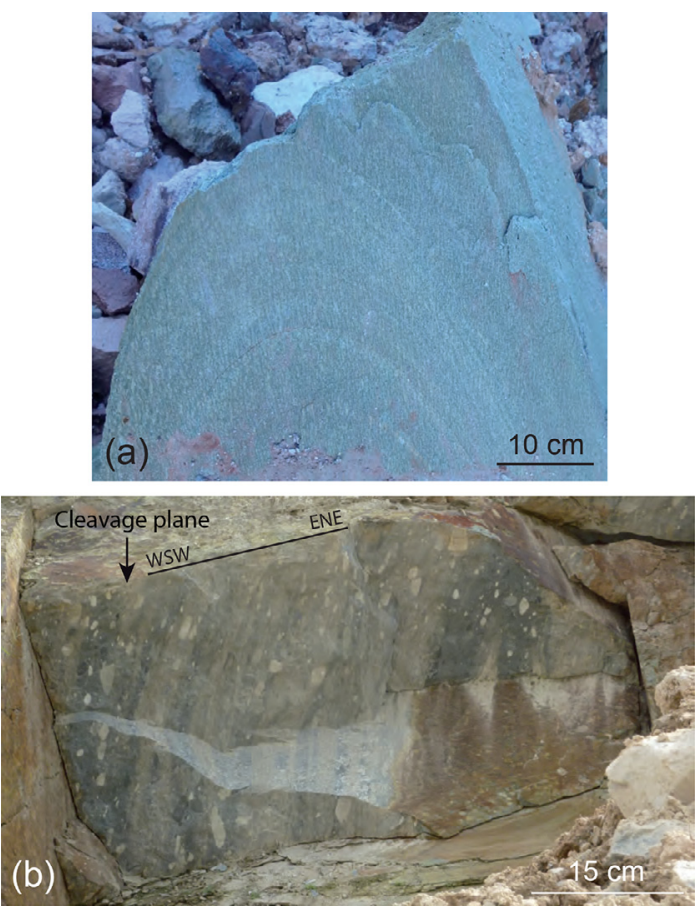

Fig. 4. Photographs illustrating pervasive structures observed in the Rosebel area. (a) Example of small-scale fold within arenites with axialplane cleavage (J Zone) (sample not in place). (b) Steeply dipping ESEWNW striking cleavage bearing a steeply plunging stretching lineation (here marked by stretched pebbles in conglomerates) (Mayo).

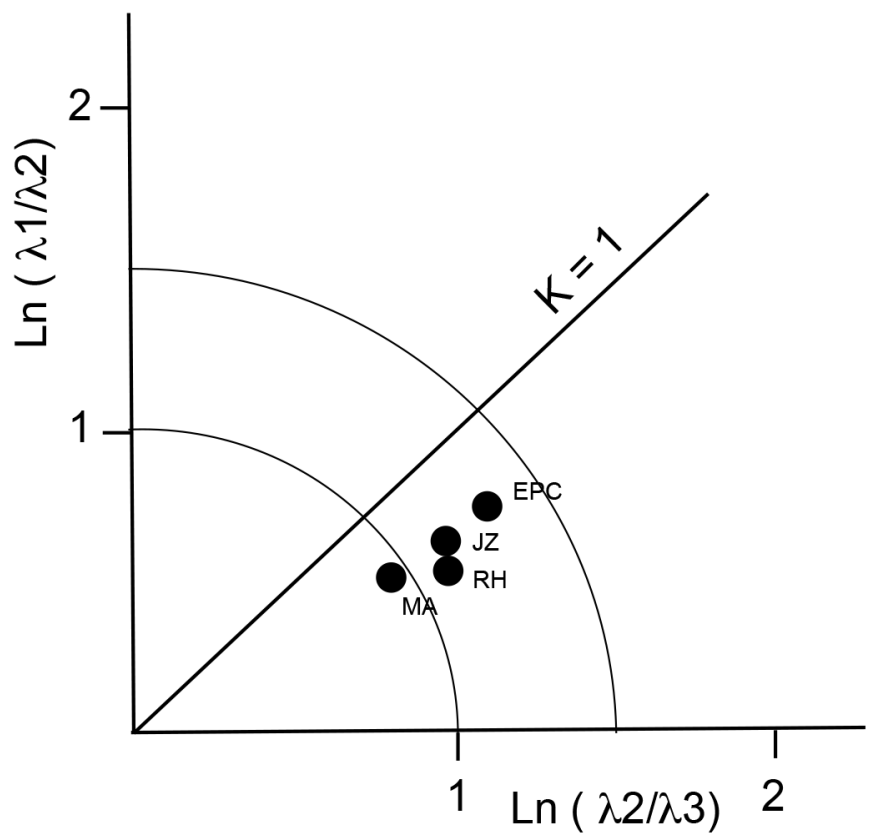

Fig. 5. Flinn diagram (after Ramsay and Huber, 1983) showing finite strains measured from pebble shapes within four pits of the Rosebel district. JZ: J Zone; EPC: East Pay Caro; MA: Mayo; RH: Royal Hill.
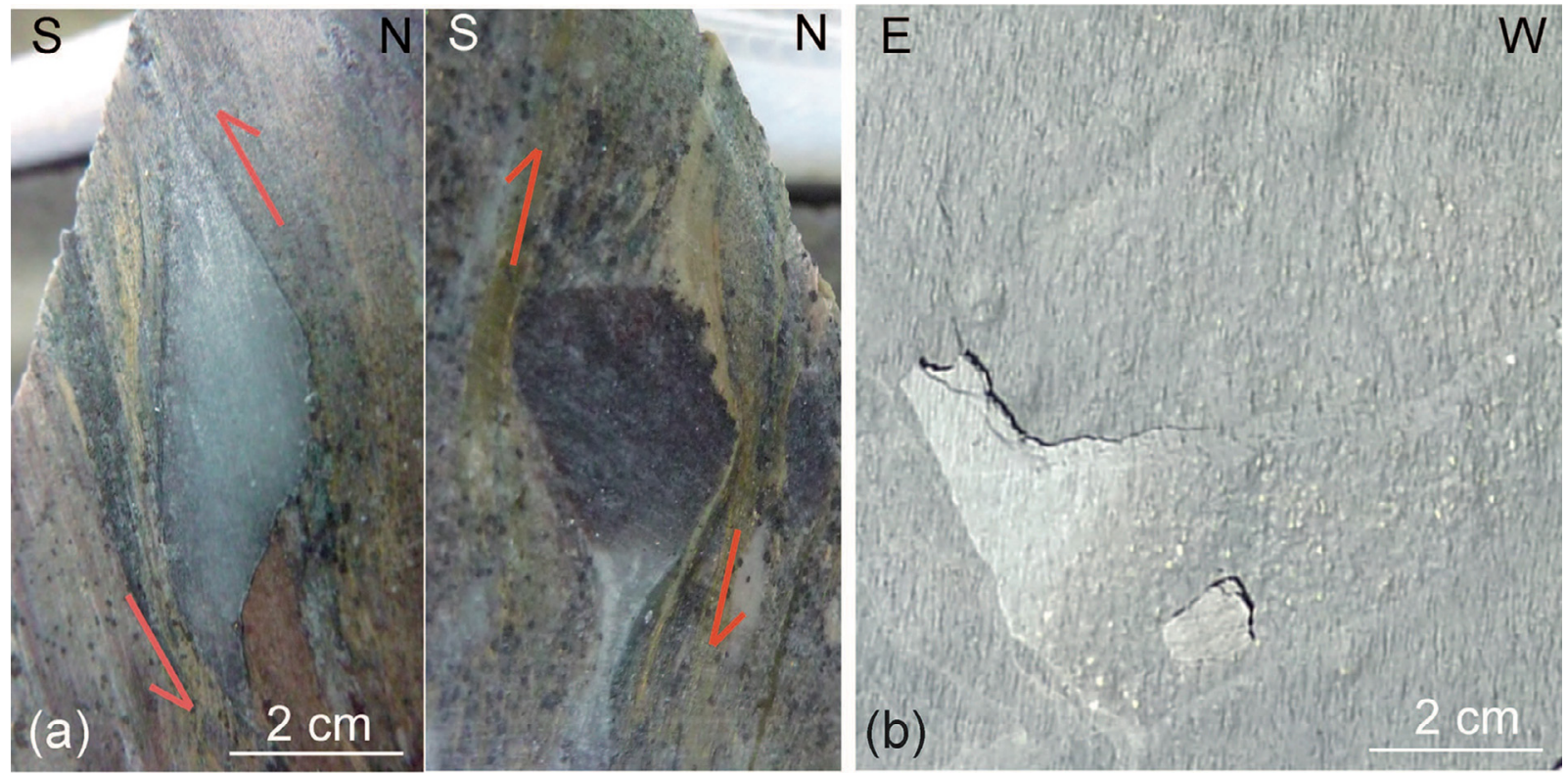

Fig. 6. (a) Examples of asymmetric shadow zone (left) and asymmetrically deformed pebble (right) in conglomerate, indicating subvertical shearing during cleavage development (drill cores from Pay Caro pit) ( $\lambda 1 \lambda 3$ planes). (b) Example of steeply plunging very fine striations on a subvertical cleavage plane (Pay Caro). 


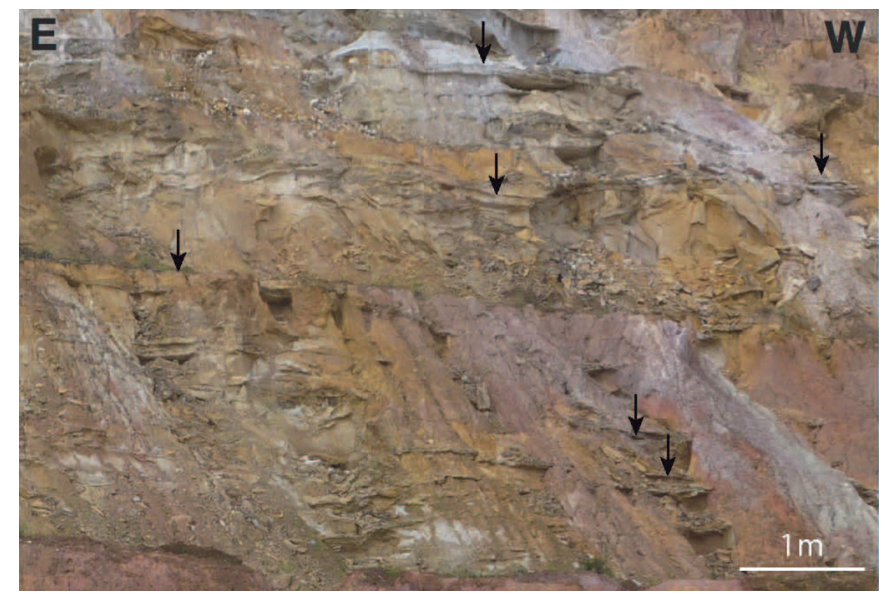

Fig. 7. Example of flat-lying veins, some being underlined by arrows (Mayo). Width of photograph is about $10 \mathrm{~m}$.

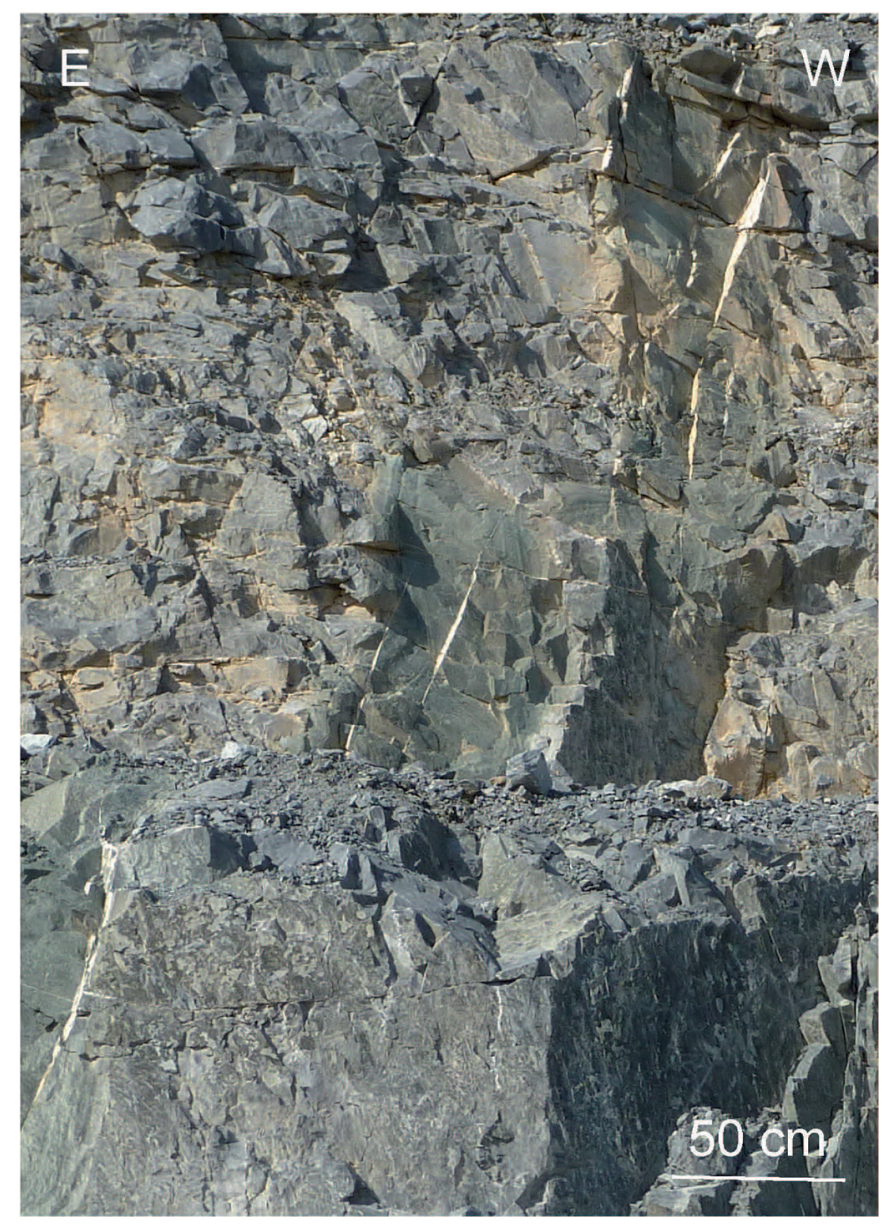

Fig. 8. Example of steeply dipping NS striking veins (Royal hill). Width of photograph is about $2 \mathrm{~m}$.

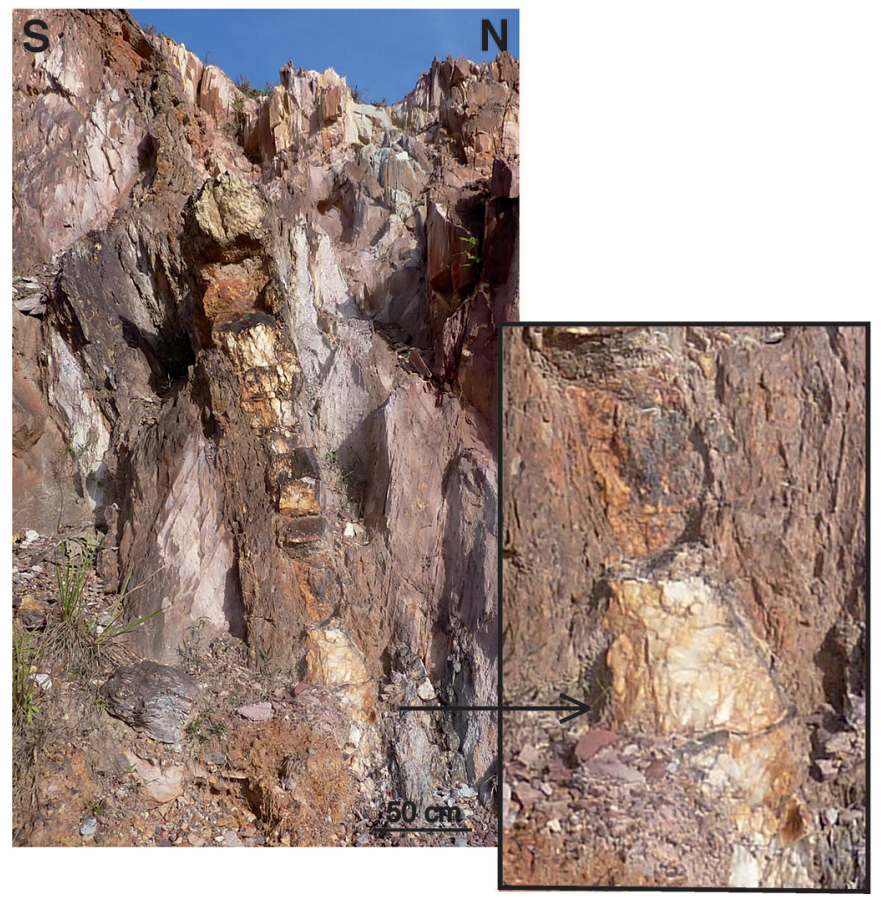

Fig. 9. Example of vein emplaced in a reverse fault at low angle to host rock cleavage (West Pay Caro). The vein shows incipient boudinage indicating vertical stretch (zoom right-hand side). Width of left-hand side photograph is about $2 \mathrm{~m}$.

between fault sets. Actually, the vein pattern suggests some stockwork pattern with strain-related preferred orientations. Veins are locally deformed, showing folding or boudinage (Fig. 9), which shows that vein arrays did emplace during regional deformation.

\section{Faults}

A prominent fault set consists of high-angle EW to WSWENE striking reverse faults (Fig. 10a, b). At outcrop scale, reverse faults may occur as conjugate sets, with significant offsets (Fig. 10b). These faults contributed to the regional horizontal shortening and to the finite steeply plunging principal stretch.

Faults with substantial strike-slip components are also numerous. Most strike parallel to the regional structural pattern. They show either dominant dextral or sinistral motions (Fig. 11). This underlines that some fault sets are incompatible in terms of kinematics, as shown in more details below.

Normal faults are also observed (Fig. 12). Their main trend is EW to WNW-ESE, consistent with that of the regional structures.

Fault attitudes and attached kinematics have been further examined using the kinematic software "Faultkin" developed by Allmendinger (Faultkin 7.5, 2016) (Marrett and Allmendinger, 1990; Allmendinger et al., 2011) based on 

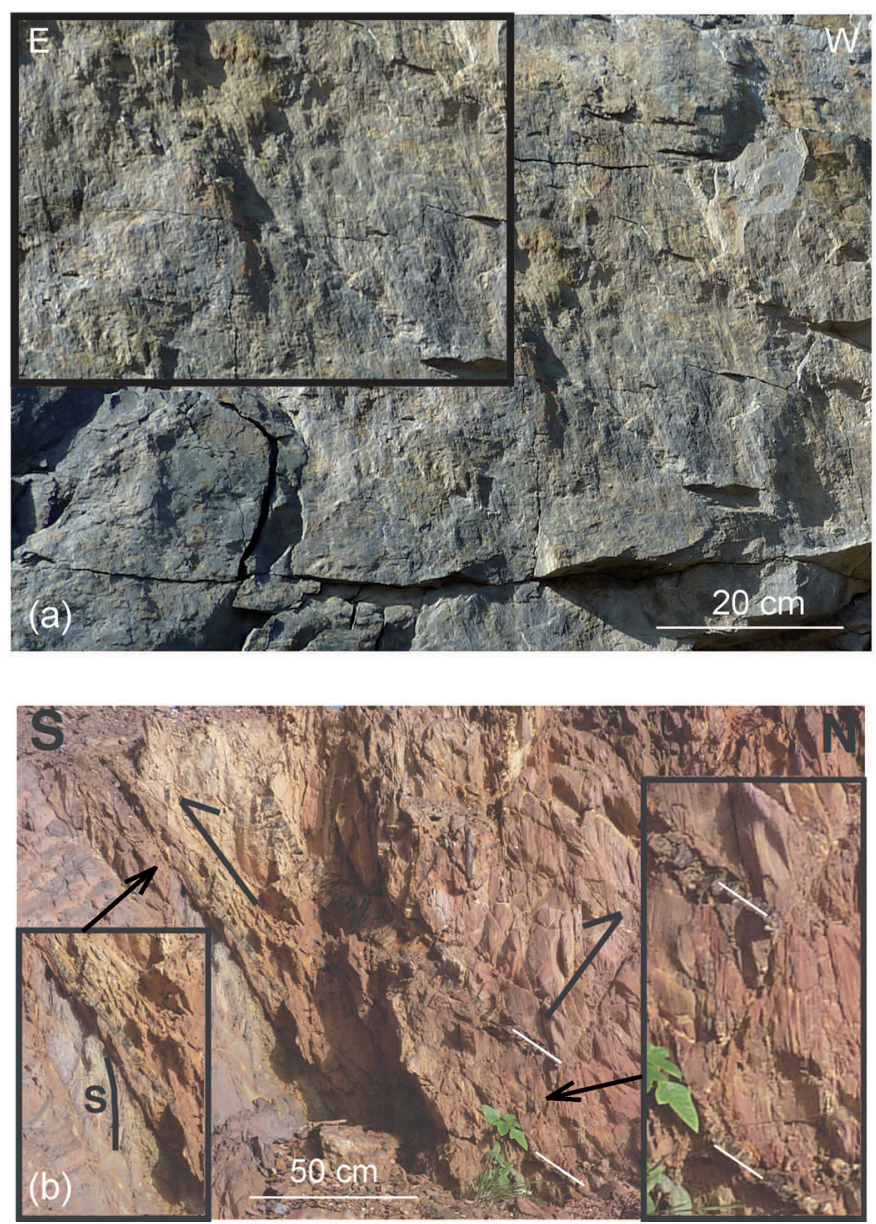

Fig. 10. (a) Example of steeply dipping south-verging reverse fault (Royal Hill). Insert shows zoom of fault surface with slickensides. Photograph looks south. (b) Example of conjugate high-angle thrusts (West Pay Caro). A 20-cm thick zone of mylonitised band is associated with the south verging fault (left). Left insert shows a zoom, S indicates mylonitic fabric. A quartz vein is offset of about $40 \mathrm{~cm}$ by the north verging fault (offset underlined by white lines, right insert).
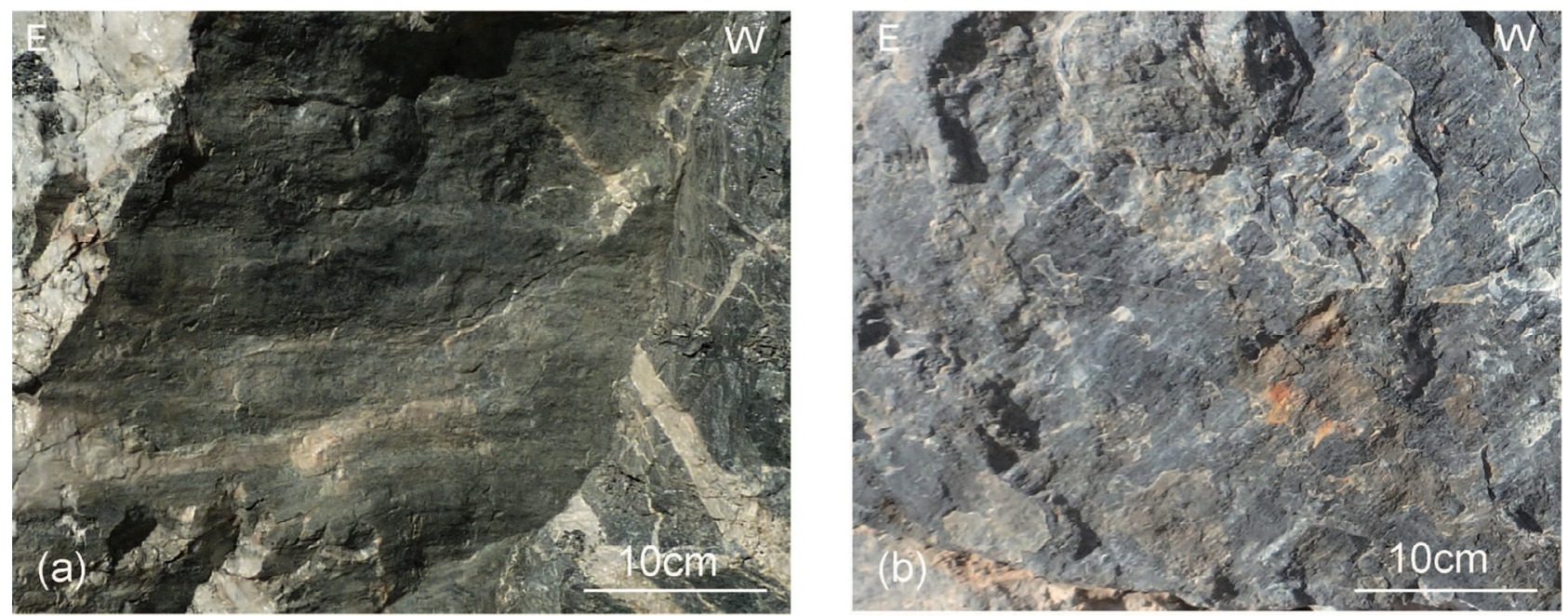

Fig. 11. Examples of strike-slip faults. (a) Dextral strike-slip fault (EW strike) (East Pay Caro). (b) Sinistral fault (EW strike) (Royal Hill). These two types of faults are sub-parallel and along-strike with respect to the basin (WNW-ESE), which emphasizes substantial kinematic incompatibilities between some sets of faults and therefore a complex faulting history of the area. 


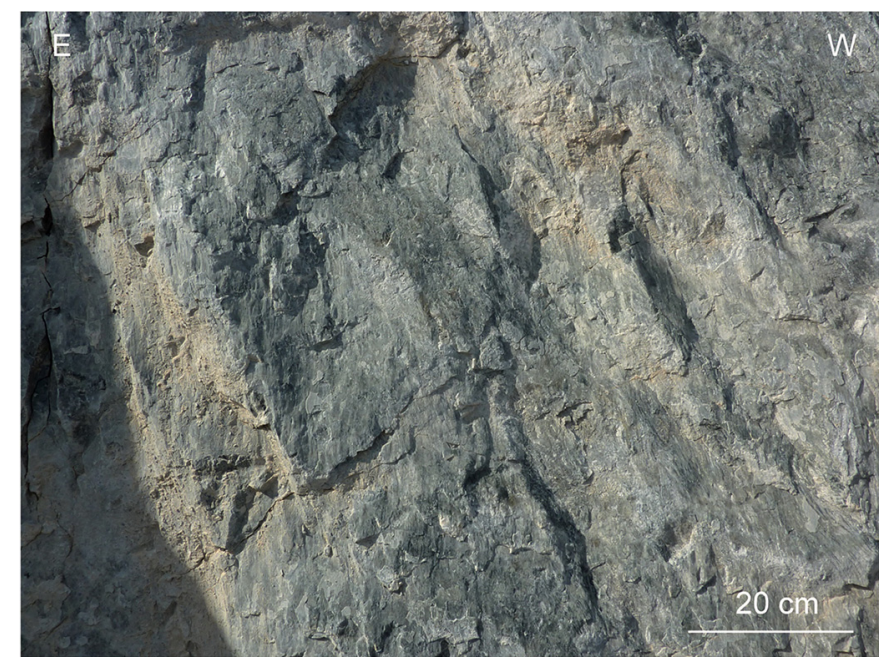

Fig. 12. Example of north-verging normal fault (Mayo). The fault strikes N115.

the right dihedral method developed by Angelier and Mechler (1977). Data were collected within four pits of the Rosebel district (J Zone, East Pay Caro, Mayo, Royal Hill) (Fig. 13). They show several features, as follows:

- sets of along strike trending faults, most being reverse, strike-slip or normal faults, are present in all sites, with some differences in associated bulk shortening directions between the northern part (J Zone and East Pay Caro) and the southern part (Royal Hill);

- the bulk stretch direction estimated from all fault patterns has substantial plunges, which is consistent with patterns of pervasive structures and veins (Figs. 4, 6 and 7);

- several fault sets are incompatible in terms of kinematics. Best examples are found in the sites of East Pay Caro and Mayo. In East Pay Caro, two main shortening directions, NW-SE and ENE-WSW, are revealed by the analysis (Fig. 13). They basically correspond to faults with dextral or sinistral components with similar along-strike trends, respectively (Fig. 11);

- the site of Mayo shows a particularly complex fault pattern, with two sub-perpendicular subhorizontal shortening directions, NNW-SSE and WSW-ENE (Fig. 13b, c). These latter are somewhat comparable to those shown by fault patterns from East Pay Caro;

- the sites of J Zone and Royal Hill show the most consistent and simple pattern, with a bulk subhorizontal NS trending shortening direction, at high angle to basin boundary and at low angle to the regional shortening direction outlined by the cleavage pattern (Fig. 2a).

\section{Discussion}

\subsection{Deformation history and basin development}

A long-lasting and polyphased deformation history was proposed for the Rosebel area by Daoust et al. (2011) and Daoust (2016). It included in particular an initial basin formation in a sinistral pull-a-part transtensional regime,

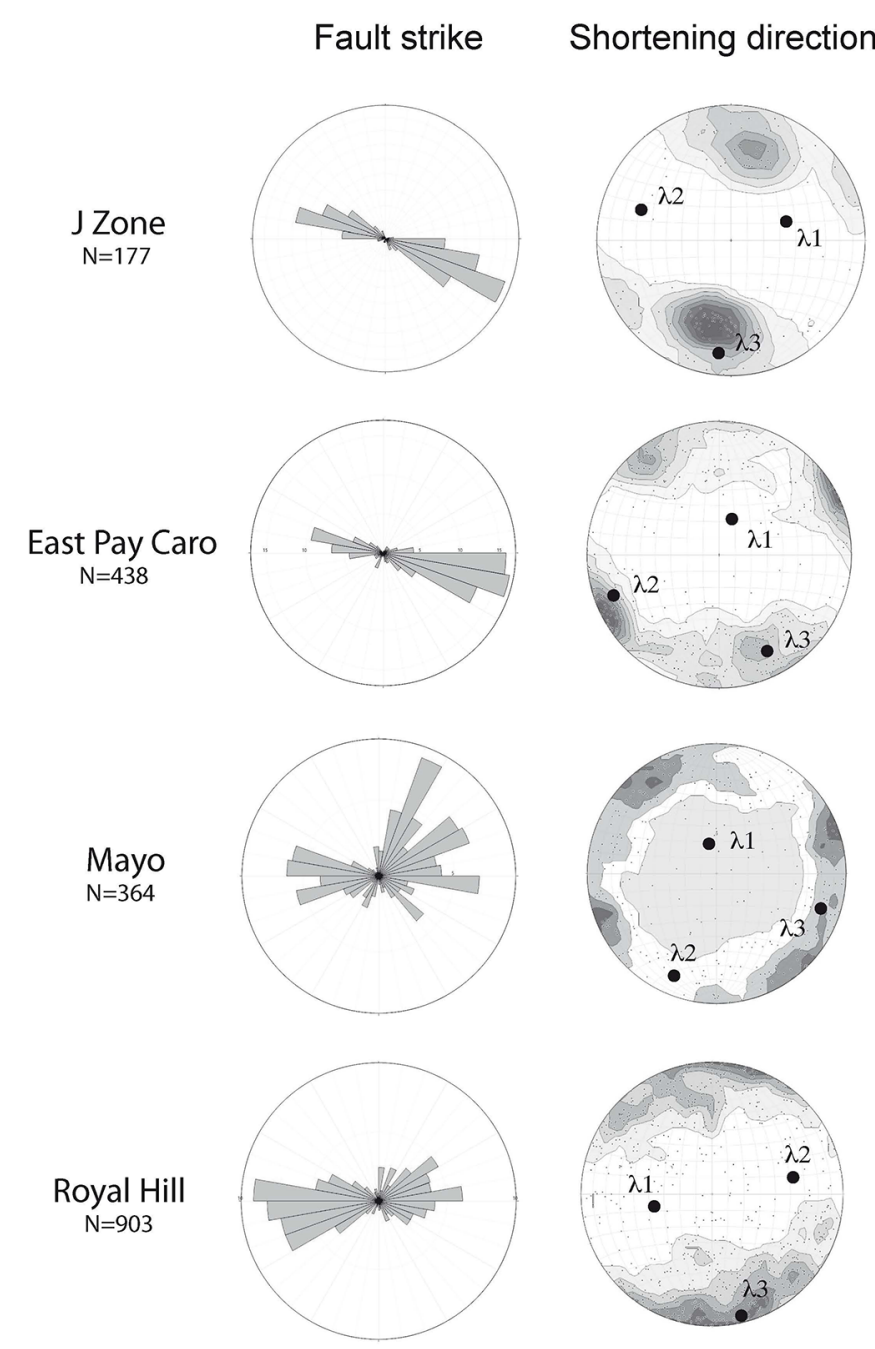

Fig. 13. Fault patterns from four sites of the Rosebel district ("Faultkin" Allmendinger's software (Marrett and Allmendinger, 1990; Allmendinger et al., 2011). Fault strike diagrams are direction rose diagrams. Stereograms for shortening directions show poles of faults, contours of associated principal shortening (equal area projection, lower hemisphere). $\lambda 1, \lambda 2, \lambda 3$ refer to bulk principal stretch, intermediate, and shortening axes, respectively. $\mathrm{N}$ refers to the number of measured faults. See text for further comments.

followed by NNE-SSW compression with folding and strike slip faulting, and NS dextral transpression increasing the steepening of earlier thrusts. Basin development in sinistral regimes was also invoked for other parts of the TransAmazonian belt (Manier et al., 1993; Ledru et al., 1991, 1994; Vanderhaeghe et al., 1998; Delor et al., 2003). Main arguments developed by these authors were sinistral shear zones along basin boundaries (e.g. Orapu basin, Guiana), and extensional shears parallel to bedding (Mana basin, Guiana).

This scenario is rather difficult to further comment in Suriname, especially because fault activities, that nevertheless attest to a complex deformation history involving thrusts, normal faults, and dextral and sinistral strike slip, did at least in part accompany the regional ductile deformation marked by 


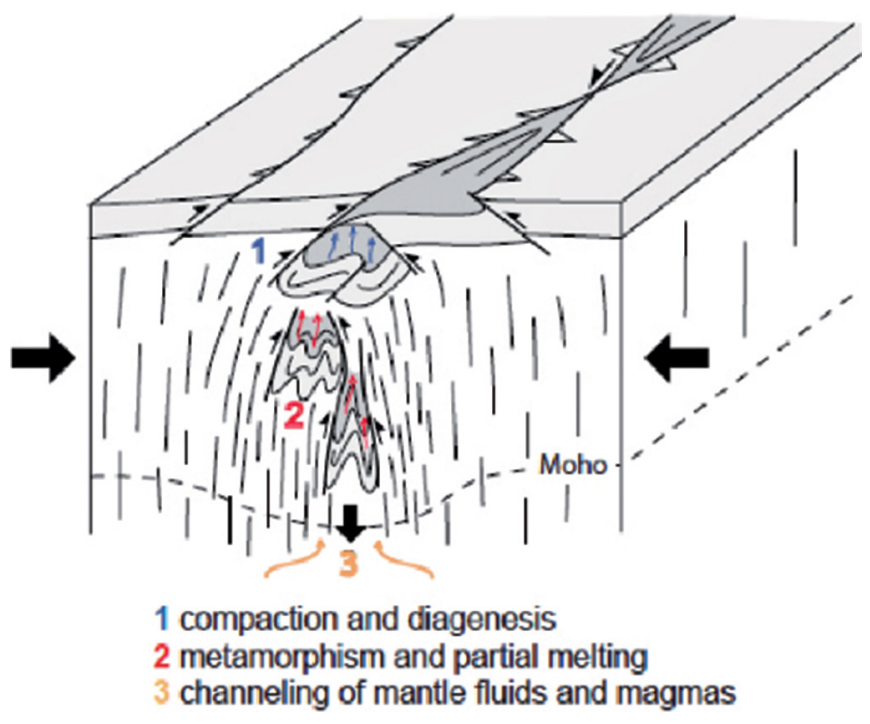

Fig. 14. General model of pop-down tectonics associated with compression of a weak continental lithosphere (after Gapais et al., 2014). The model emphasizes that vertical deformation zones associated with burial of supracrustals are particularly favourable for production and transfers of various types of fluids that may contribute to mineralisations. See text for further explanations and relationships to the study area.

folding and cleavage development. In addition, as pointed out by detailed works in the Rosebel district (Daoust et al., 2011; Daoust, 2016), an unequivocal chronology between the different fault sets is rather difficult to establish in the area. An early sinistral regime during onset of basin development in a pull-a-part context might be likely, but cannot be here further argued. Perhaps, the ENE-WSW shortening component revealed by fault patterns in East Pay Caro and Mayo sites, consistent with some WNW-ESE sinistral shearing and inconsistent with the observed regional NW-SE shortening, should be further explored.

\subsection{Finite strain pattern and tectonics}

Structural data indicate dominant components of vertical stretching and associated vertical motions. This is shown by steeply dipping cleavages (Fig. 4b), steeply plunging stretching lineations (Fig. 4b), attached kinematic indicators (Fig. 5), flat-lying vein sets (Fig. 7), and high-angle reverse faults (Fig. 10).

A convenient model that may account for dominant vertical tectonics during horizontal shortening is the "popdown" model proposed by Cagnard et al. (2006a, 2006b) and further developed by Chardon et al. (2009) and Gapais et al. (2009, 2014) (Fig. 14). This model does not require reverse gravity jumps as those involving sagduction and/or diapirism like those extensively developed for Archean greenstone belts (see Chardon et al., 2009 and references therein). It just requires a weak lithosphere submitted to compression. Popdown tectonics may thus account for deformation patterns of several Archaean belts, but also Paleoproterozoic belts and associated various mineralisations (Gapais et al., 2014; Gapais, 2018). Indeed, pop-down tectonics in compressional contexts may lead to downward motions of light upper-crustals within underlying weak middle and lower crust (Cagnard et al., 2006a, 2006b). Pop-down tectonics may further account for along strike subparallel steep reverse and normal faults. During basin burial, Pop-downs may indeed be bounded by faults along which either thrust or normal motions can occur (Fig. 14). The structural pattern of the Rosebel area, marked by low-grade metamorphism and ductile deformation of sediments, combined with brittle deformations along basin boundaries, might well represent early stages of the popdown model developed by Cagnard et al. (2006a, 2006b) and Gapais (2018), with associated potential diagenetic and metamorphic fluids, as well as associated mineralisations (stages 1 and early 2, Fig. 14). Structural evidence described previously shows that thrusting along basin boundaries and ductile deformations within it were coeval. Furthermore, kinematic indicators are consistent with basin burial (Fig. 6). Of course, some subsequent deformations might have accumulated during later exhumation, but this is likely to have still occurred in transpressive conditions, thus mainly erosion-driven, as no evidence of important late extension was observed (see also Daoust et al., 2011).

\subsection{Wrenching components}

Outcrop-scale wrench faults do occur in the Rosebel area (Figs. 11 and 13). They imply a complex faulting history, as underlined by both dextral and sinistral faults with similar strikes (Figs. 11 and 13); but no field evidence demonstrates unequivocal chronological succession of these different fault motions. At the scale of individual faults, displacements appear limited, and geological maps do not show regionalscale offsets of units.

A regional transpressive regime is however quite likely to have occurred in the Rosebel area, especially because transpression results in flattening strains (see Dewey et al., 1998; Merle and Gapais, 1997), which is shown by our strain analysis in conglomerates (Fig. 5). On the other hand, no evidence of important strike-slip component is observed within the basin, neither of important horizontal offsets of units or unit boundaries at map scale (Fig. 1). In overall, metamorphic and structural features observed basically reflect basin burial.

Analogue models and field examples have shown that compressive pop-downing may be accompanied by horizontal longitudinal flow of the partially melted middle and lower crust (Cagnard et al., 2006b; Chardon et al., 2009; Gapais et al., $2009,2014)$. In analogue models, horizontal flow is heterogeneous between crustal blocks separated by zones of pop-down piling up (Cagnard et al., 2006b). This results in transfer zones with strike-slip components that accommodate variable amounts of longitudinal crustal flow and associated different rotations of upper crustal blocks. These transfer zones rotate during progressive shortening, and complex deformation histories may occur along them. Deformation zones marked out by supracrustals and involving strike-slip components are very common in Archaean and Paleoproterozoic cratons (Cagnard et al., 2006b; Chardon et al., 2009; Gapais et al., 2014; Gapais, 2018). Further work is needed to discuss the role and kinematics of transfer zones associated with pop-down tectonics. 


\section{Concluding remarks}

From our structural analysis of the gold Rosebel district in Suriname, we outline the following remarks:

- the first-order structural feature is vertical stretch associated with both ductile and brittle deformations;

- finite strains are of flattening type, which is consistent with transpressive motions;

- the structural evolution of the basin is marked by a fault pattern that shows a complex deformation history. Nevertheless, many faults and veins attest to horizontal shortening and vertical stretch;

- the overall structural pattern is compatible with vertical burial of supracrustals in a transpressive regime associated with pop-down tectonics;

- results and tectonic interpretations provided here for the Rosebel district may be promising for other areas of the gold-bearing Trans-Amazonian belt.

Acknowledgements. Most data presented in this paper were gathered by IAMGOLD and SUREX Companies, and by DG. DG benefited from field work organised by IAMGOLD in summer 2016. Two anonymous reviewers helped to improve the paper.

\section{References}

Allmendinger RW, Cardozo N, Fisher D. 2011. Structural geology algorithms: vectors and tensors in structural geology. Cambridge University Press, 302 p., ISBN 978-1-10-740138-9.

Angelier J, Mechler P. 1977. Sur une méthode graphique de recherche des contraintes principales également utilisable en tectonique et en sismologie : la méthode des dièdres droits. Bull Soc Géol Fr 7 (XIX, 6): 1309-1318.

Bardoux M, Moroney M, Robert F. 2018. Gold mineralization in the Guiana Shield, Guiana and Suriname, South America: a field trip to the 14th biennial Society for Geology Applied to Mineral Deposits (SGA) meeting. Geological Survey of Canada, Open File 8351, 28 p. https://doi.org/10.4095/306546.

Cagnard F, Brun JP, Gapais D. 2006a. Modes of thickening of analogue weak lithospheres. Tectonophysics 421: 145-160.

Cagnard F, Durrieu N, Gapais D, Brun JP, Ehlers C. 2006b. Crustal thickening and lateral flow during compression of hot lithospheres, with particular reference to Precambrian times. Terra Nova 18: 72-78.

Chardon D, Gapais D, Cagnard F. 2009. Flow of ultra-hot orogens: a view from the Precambrian, clues for the Phanerozoic. Tectonophysics 477: 105-118.

Daoust C. 2016. Caractérisation stratigraphique, structurale et géochimique du district minéralisé de Rosebel (Suriname) dans le cadre de l'évolution géodynamique du bouclier guyanais. $\mathrm{PhD}$. Thesis. UQAM, $353 \mathrm{p}$.

Daoust C, Voicu G, Brisson H, Gauthier M. 2011. Geological setting of the Paleoproterozoic Rosebel gold district, Guiana Shield, Suriname. J South Am Earth Sci 32: 222-245.

Delor C, Lahondère D, Egal E, Lafon J-M., Cocherie A, Guerrot C, et al. 2003. Transamazonian crustal growth and reworking as revealed by the 1:500,000 scale geological map of French Guiana. Géologie de la France 2-3-4: 5-57.

Dewey JF, Holdsworth RE, Strachan RA. 1998. Transpression and transtension zones. In: Holdworth RE, Strachan RA, Dewey JF, eds. Continental transpressional and transtensional tectonics. Geol Soc Lond Spec Publ 135: 1-14.

Gapais D. 2018. Tectonics-mineralisations relationships within hot continental lithospheres: a new structural framework for Precambrian cratons. BSGF - Earth Sciences Bulletin 189(3): 14.

Gapais D, Cagnard F, Gueydan F, Barbey P, Ballèvre M. 2009. Mountain building and exhumation processes through time: inferences from nature and models. Terra Nova 21: 188-194.

Gapais D, Jaguin J, Cagnard F, Boulvais P. 2014. Pop-down tectonics, fluid channelling and ore deposits within ancient hot orogens. Tectonophysics 618: 102-106.

Ledru P, Lasserre JL, Manier E, Mercier D. 1991. Le Protérozoïque inférieur nord-guyanais: révision de la lithologie, tectonique transcurrente et dynamique des bassins sédimentaires. Bull Soc Geol Fr 162(4): 627-636.

Ledru P, Johan V, Milési JP, Tegyey M. 1994. Markers of stages of the Palaeoproterozoic collision: evidence for a $2 \mathrm{Ga}$ continent involving circum-South Atlantic provinces. Precamb Res 69: 169-191.

Manier E, Mercier D, Ledru P. 1993. Alluvial basin-fill dynamics and gold-bearing aspects of Early Proterozoic strike-slip basins in French Guiana. Spec Publ Inst Ass Sediment 17: 553-568.

Marrett RA, Allmendinger RW. 1990. Kinematic analysis of fault-slip data. J Struct Geol 12: 973-986.

Merle O, Gapais D. 1997. Strain within thrust-wrench zones. J Struct Geol 19: 1011-1014.

Milési JP, Egal E, Ledru P, Vernhet Y, Thiéblemont D, Cocherie A, et al. 1995. Les mineralizations du Nord de la Guyane Française dans leur cadre géologique. Chronique de la Recherche Minière 518: 5-58.

Milési JP, Lerouge C, Delor C, Ledru P, Billa M, Cocherie A, et al. 2003. Gold deposits (gold-bearing tourmalinites, gold-bearing conglomerates, and mesothermal lodes), markers of the geological evolution of French Guiana. Geology, metallogeny, and stable isotope constraints. Géologie de la France 2-3-4: 257-290.

Ramsay JG. 1967. Folding and fracturing of rocks. McDrawHill, $568 \mathrm{p}$.

Ramsay JG, Huber MI. 1983. The techniques of modern structural geology. Volume 1: Strain analysis. London: Academic Press, 307 p.

Vanderhaeghe O, Ledru P, Thiéblemont D, Egal E, Cocherie A, Teygey M, et al. 1998. Contrasting mechanism of crustal growth Geodynamic evolution of the Paleoproterozoic granite-greenstone belts of French Guiana. Precamb Res 92: 165-193.

Cite this article as: Gapais D, Alimoenadi G, Balraadjsing N, Poupeau B. 2021. The Rosebel gold mining district (Trans-Amazonian belt, Suriname), a new structural framework, BSGF - Earth Sciences Bulletin 192: 32. 